\title{
RANCANG ULANG KEMASAN PRODUK MAKANAN BEKU BERBAHAN DASAR SEAFOOD GUNA PENINGKATAN PANGSA PASAR DI ERA PANDEMI COVID-19
}

\author{
Lithrone Laricha Salomon ${ }^{1}$, Ahmad ${ }^{1}$, Wilson Kosasih ${ }^{1}$ dan I Wayan Sukania ${ }^{1}$
}

${ }^{1}$ Program Studi Teknik Industri, Universitas Tarumanagara, Jakarta

Email: lithrones@ft.untar.ac.id

\begin{abstract}
The current era of the Covid-19 pandemic has caused a decline in the level of a person's economy / income, which will raise concerns of many things. One of them is in the selection of food ingredients. Many people today want a food product that is affordable but still hygienic. This has resulted in a decrease in consumption of a number of eating establishments where many people have switched to processing their own food. In addition to the hygienic factor, this decrease is also based on the level of consumer saturation with the products being offered. Based on these conditions, it is necessary to carry out a strategy to increase product marketing, in this case, is to make frozen seafood products in packaging. Seeing the current pandemic condition, consumers are very concerned about the hygiene factor of a product. The existence of this seafood-based frozen food product aims to make it easier for consumers to cook a variety of seafood dishes at their respective homes at the time the consumers want themselves. This product packaging redesign is a strategy that is expected to increase the market share of products produced by MSMEs that produce frozen seafood-based foods. It can be said that MSMEs producing frozen seafood-based food do not understand the overall market demand for frozen seafood products, so it is necessary to know consumer preferences for frozen seafood products, both in terms of taste and packaging quality that can meet consumer desires. Through the initial research conducted, the results of the product packaging redesign were obtained which could increase the sales of this seafoodbased frozen food product.
\end{abstract}

Keywords: Frozen food, Seafood, redesign packaging, consumer preference.

\begin{abstract}
ABSTRAK
Era pandemi Covid-19 saat ini membuat turunnya tingkat ekonomi/pendapatan seseorang dimana hal ini akan menimbulkan kekhawatiran akan banyak hal. Salah satunya adalah dalam hal pemilihan bahan pangan. Banyak orang saat ini menginginkan suatu produk makanan dengan harga terjangkau namun tetap higienis. Hal ini mengakibatkan terjadinya penurunan konsumsi terhadap sejumlah tempat makan dimana banyak orang beralih untuk mengolah makanannya sendiri. Selain faktor higenitas penurunan ini juga didasari adanya tingkat kejenuhan konsumen terhadap produk yang ditawarkan. Berdasarkan kondisi tersebut maka perlu dilakukan suatu strategi untuk dapat meningkatkan pemasaran produk dalam hal ini adalah membuat produk frozen seafood dalam kemasan. Melihat kondisi pandemi saat ini, konsumen sangat memperhatikan faktor higinitas dari suatu produk. Adanya produk makanan beku berbahan dasar seafood ini bertujuan untuk memudahkan konsumen dalam memasak beragam hidangan seafood di rumah masing-masing pada waktu yang diinginkan konsumen itu sendiri. Rancang ulang kemasan produk ini merupakan suatu strategi yang diharapkan dapat meningkatkan pangsa pasar terhadap produk yang dihasilkan oleh UMKM penghasil makanan beku berbahan dasar seafood. UMKM penghasil makanan beku berbahan dasar seafood yang ada saat ini dapat dikatakan belum memahami keinginan pasar secara menyeluruh dari produk frozen seafood yang dibuat sehingga sangat perlu diketahui preferensi konsumen terhadap produk hidangan Frozen seafood baik dari aspek kualitas rasa maupun kemasan yang dapat memenuhi keinginan konsumen. Melalui penelitian awal yang dilakukan maka diperoleh hasil redesign kemasan produk yang dapat meningkatkan penjualan produk makanan beku berbahan dasar seafood ini.
\end{abstract}

Kata kunci: Makanan beku, Seafood, rancang ulang kemasan, preferensi konsumen

\section{PENDAHULUAN}

Usaha Mikro Kecil dan Menengah (UMKM) merupakan usaha yang berdiri sendiri yang dilakukan perorangan atau suatu badan usaha. Menurut Keputusan Presiden RI no. 99 tahun 1998 pengertian Usaha Kecil adalah "Kegiatan ekonomi rakyat yang berskala kecil dengan bidang usaha yang secara mayoritas merupakan kegiatan usaha kecil dan perlu dilindungi untuk mencegah dari persaingan usaha yang tidak sehat". Pada laman kominfo.go.id tercatat bawah terdapat 59,2 juta pelaku UMKM yang ada di Indonesia. Angka tersebut dapat diartikan sebagai banyaknya persaingan yang terjadi pada Usaha Kecil dan Menengah. UMKM yang akan dibantu adalah UMKM yang menghasilkan hidangan seafood. Hidangan yang ditawarkan berupa hewan laut 
seperti kepiting, cumi-cumi, udang dan sebagainya. Salah satu UMKM seafood ini yaitu Seafood 21 Pekayon Jaya merupakan restoran yang memiliki menu andalan beragam jenis seafood seperti cumi, udang, ikan, dan kerang.

UMKM Seafood 21 Pekayon Jaya selalu menjamin komoditi seafood-nya berada pada kondisi segar. Ini merupakan salah satu strategi yang diterapkan untuk mengembangkan usahanya tersebut. Kondisi Pandemi ini menyebabkan UMKM Seafood 21 Pekayon Jaya mengalami penurunan penjualan dikarenakan turunnya kemampuan ekonomi suatu keluarga ataupun rasa cemas akan ketidakhigienisan produk. Penurunan ini juga didasari adanya tingkat kejenuhan konsumen terhadap produk yang ditawarkan. Terjadi penurunan penjualan sebesar 46 persen terhitung dari awal pandemic bulan Maret 2020 hingga Desember 2020.

Hal tersebut memunculkan ide untuk membuat produk dalam bentuk beku yang dikemas sehingga memudahkan konsumen dalam mengkonsumsi dan lebih higienis. Ide ini harus dikaji dan sangat berkaitan dengan preferensi konsumen. Kondisi saat ini, produsen belum bisa mengidentifikasikan atribut yang menjadi pertimbangan utama masyarakat dalam membeli produk makanan seafood. Hal ini menyebabkan terjadinya penurunan penjualan. Lemahnya daya saing tersebut antara lain disebabkan oleh desain kemasan produk yang kurang menarik seperti dapat dilihat pada Gambar 1 untuk desain kemasan produk yang sudah ada; jalur distribusi produk yang kurang baik; strategi promosi yang masih tradisional serta belum memiliki jejaring bisnis yang luas. Apabila atribut yang diinginkan konsumen telah terpenuhi, maka permintaan produk juga akan meningkat. (Salomon et al., 2020).

\section{Gambar 1}

\section{Desain Kemasan Produk Saat Ini}

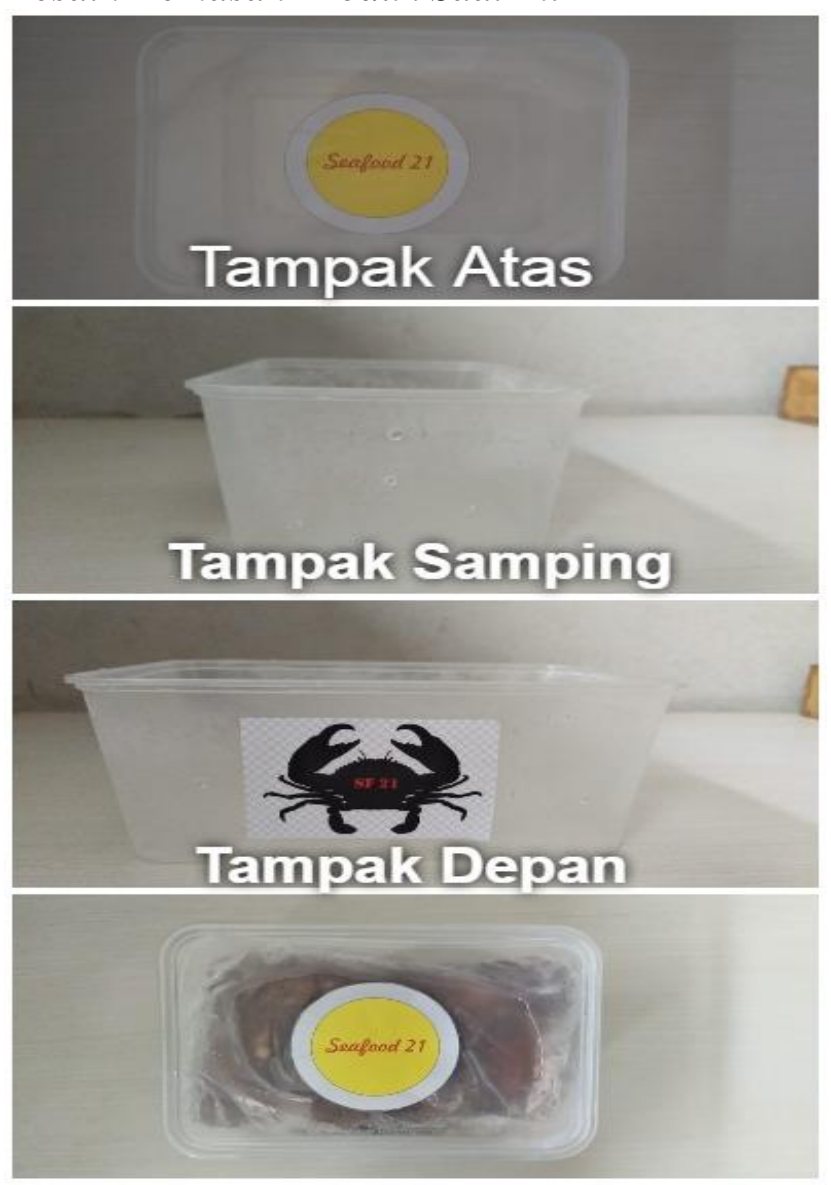


Selain dari pihak produsen dalam hal ini konsumen juga menghadapi dilema dari banyaknya penawaran yang mereka dapatkan. Konsumen akan melihat produk yang ditawarkan dari berbagai macam sisi. Semakin tingginya persaingan suatu usaha akan memaksa konsumen semakin selektif melihat produk yang ditawarkan. Oleh karena itulah sangat perlu untuk mengetahui preferensi konsumen guna meningkatkan penjualan atau keuntungan suatu usaha. Dengan mengetahui preferensi konsumen, diharapakan dapat memberikan suatu produk atau jasa yang mampu memberikan kepuasan kepada konsumen (Salomon et al., 2019).

Salah satu metode untuk menggambarkan preferensi konsumen adalah metode conjoint analysis. Menurut Kotler et al. (2008), preferensi konsumen adalah pilihan suka atau tidak suka oleh seseorang terhadap produk (barang atau jasa) yang dikonsumsi. Dimana preferensi konsumen merupakan informasi dari kesukaan konsumen dari berbagai pilihan produk yang ada. Informasi preferensi konsumen tentu digunakan untuk menaikkan kepuasan konsumen terhadap produk perusahaan. Pendekatan kepuasan ini dan preferensi konsumen merupakan salah satu aktivitas perancangan dan pengembangan produk. Penggunaan conjoint analysis juga mampu mengevaluasi produk komplek yang dilihat dari konteks keputusan konsumen yang realistis. Selain itu, dapat diketahui penilaian tingkat kepentingan masing-masing atribut dimana konsumen hanya mengevaluasi profil produk yang sedikit (Hair et al., 2014).

Conjoint analysis merupakan penurunan komponen psikologis yang dapat diukur dalam hal utilitas. Dalam memahami keputusan konsumen ada dua tujuan dasar conjoint analysis yaitu menentukan kontribusi atribut serta levelnya dalam menentukan kebutuhan konsumen dan membentuk model yang valid dari penilaian konsumen sehingga memungkinkan untuk memprediksi penerimaan konsumen dari kombinasi atribut (Hair et al., 2009). Selain itu menurut Isti Surjandari pada bukunya "Conjoint Analysis: Konsep dan Aplikasi", keluaran utama dari conjoint analysis adalah serangkaian skala interval "part-worths" atau utilitas dari masing-masing level untuk setiap atribut produk. Teknik ini berdasarkan premis sederhana bahwa konsumen mengevaluasi nilai dari suatu produk (Surjandari, 2010).

Berdasarkan latar belakang yang ada maka dapat disimpulkan permasalahan yang terjadi pada mitra yaitu belum diketahuinya preferensi konsumen terhadap produk hidangan beku seafood dalam kemasan begitu pula terhadap rancangan desain kemasan produk yang ditawarkan. Mitra sangat berharap mendapatkan bantuan untuk menentukan preferensi konsumen sehingga dapat meningkatkan kembali penjualan mereka walau dalam kondisi yang masih sama. Sebagai upaya untuk menarik minat konsumen terhadap produk hidingan beku seafood yang ada adalah dengan cara memenuhi kebutuhan konsumen baik dari segi kualitas produk secara umum dalam hal ini rasa dan juga atribut pendukungnya sehingga penjualan produk ini dapat terus meningkat.

Masalah yang ditemukan saat ini adalah produsen belum bisa memenuhi kebutuhan konsumen dalam berbagai aspek secara menyeluruh. Dalam hal ini produsen belum bisa mengidentifikasikan atribut yang menjadi pertimbangan utama masyarakat dalam hidangan beku seafood dalam kemasan. Masalah selain itu adalah produsen belum dapat merumuskan strategi pemasaran untuk dapat memperluas pangsa pasarnya. Beberapa hal tersebut diatas dapat menyebabkan tingkat penjualan produk hidangan beku seafood dalam kemasan yang dihasilkan oleh UMKM ini belum mengalami peningkatan secara signifikan. Pada umumnya produsen cenderung hanya memperhatikan aspek rasa sementara atribut lain seperti bentuk, kemasan dan inovasi lainnya kurang mendapat perhatian. Solusi yang ditawarkan adalah menentukan preferensi konsumen terhadap produk hidangan beku seafood dengan menggunakan metode conjoint analysis dan melakukan perancangan ulang kemasan produk sesuai dengan preferensi konsumen yang diperoleh. 


\section{METODE PELAKSANAAN PKM}

Solusi yang ditawarkan atas permasalah mitra adalah melakukan pembuatan rancang ulang produk dalam hal ini adalah kemasan dan penentuan varian rasa yang paling digemari konsumen. Dimana rancang ulang produk tersebut merupakan hasil dari preferensi konsumen terhadap produk dengan menggunakan metode conjoint analysis dan diawali dengan penyebaran kuesioner kepada para konsumen. Atribut yang terdapat dalam kuesioner pendahuluan adalah terdiri dari:

1. Berat Isi: Atribut berat isi memiliki dua level atribut, dengan berat yang berbeda. Level atribut tersebut adalah 300 - 450 Gram dan 500 - 650 Gram

2. Banyaknya Saus : Atribut banyaknya saus merupakan jumlah saus dalam gram yang ada pada kemasan. Saus nantinya akan dihidangkan pada kemasan, banyaknya saus sendiri memiliki dua buah level, yaitu 100 - 125 Gram dan 125 - 150 Gram.

3. Varian Rasa : Atribut varian rasa merupakan kombinasi dari bahan-bahan masakan yang menciptakan sebuah rasa khas pada saus. Varian rasa memiliki tiga buah level dengan rasa khas masing-masing yaitu Saus Padang, Saus Lada Hitam, Saus Special 21.

4. Cara Membuka : Atribut cara membuka merupakan cara untuk membuka kemasan (standing pouch). Atribut cara membuka dibagi menjadi dua level yaitu Zipper dan Breakable.

5. Desain Luar : Atribut desain luar merupakan tampilan luar dari kemasan hidangan seafood beku. Kemasan yang digunakan adalah standing pouch dengan bahan dasar plastik. Atribut ini terdiri dari Tampilan luar menggunakan bantuan stiker yang menempel pada standing pouch dan Kemasan luar ditempel dengan stiker setengah bagian dan Kemasan luar ditempel dengan stiker menutupi hampir semua bagian

6. Desain dalam : Atribut desain dalam merupakan kondisi di dalam kemasan. Atribut ini dibagi menjadi dua level yaitu Terpisah dan Tidak Terpisah.

Berdasarkan kuesioner yang diberikan kepada responden hasil yang diperoleh berdasarkan survey awal kepelanggan adalah terpilih kombinasi atribut berat isi sebesar 500-600 gram, banyak saus 125-150 gram, varian rasa saus padang, kemasan produk menggunakan zipper, dengan desain luar ditempel sticker menutupi hampir semua bagian, dan desain dalam tidak terpisah.

Langkah - langkah solusi bidang produksi yang dilakukan adalah dengan membuat kerjasama dengan mitra terkait dan berupaya menyelesaikan masalah yang dihadapi yaitu adanya penurunan pada penjualan produk hidangan seafood pada masa pandemi ini. Hal ini tentunya sangat berhubungan dengan pemasukan yang diperoleh dan kelangsungan usaha yang ada. Setelah pihak mitra bersedia bekerja sama maka langkah selanjutnya adalah pihak mitra memberikan kesempatan pada tim untuk melakukan penelitian awal untuk mengetahui langkah yang harus dilakukan kedepannya. Tahap akhir adalah pihak mitra bersedia untuk melakukan implementasi terkait hasil penelitian awal yang diperoleh dan bersedia memberikan informasi terkait apakah terjadi peningkatan penjualan yang cukup signifikan setelah dilakukan perbaikan.

Secara keseluruhan, ringkasan kegiatan PKM ini adalah sebagai berikut:

a. Perencanaan : Awalnya,diusulkan proposal dengan tujuan untuk mendapatkan pendanaan kegiatan ini, termasuk pembentukan tim. Dan juga menjalin komunikasi dengan Mitra, dalam hal ini adalah perusahaan UMKM dengan nama Seafood 21 Pekayon Jaya yang terletak di Pekayon, Bekasi.

b. Pengorganisasian : Mengatur waktu pelaksanaan mulai dari observasi awal dan melakukan koordinasi antar-tim dalam menyiapkan berbagai perlengkapan dan sarana yang diperlukan.

c. Pelaksanaan : Kegiatan ini diselenggarakan pada semester genap 2020/2021. 
d. Pengendalian : Hasil pengembangan berupa menjelaskan hasil tentang variabel dalam conjoint analysis dan pengaruhnya terhadap peningkatan penjualan produk pada UMKM Seafood 21 Pekayon Jaya. Kemudian melakukan pembuatan rancangan dan realisasi produk hidangan beku seafood dalam kemasan berbasis conjoint analysis di UMKM Seafood 21 Pekayon Jaya. Setelah dilakukan pembuatan maka mencoba untuk melakukan penjualan dan memperoleh data terkait peningkatan penjualan produk setelah dilakukan perubahan rancangan kemasan.

e. Evaluasi : Setelah diperoleh hasil penjualan dan memperoleh data terkait peningkatan penjualan produk setelah dilakukan perubahan rancangan kemasan Tahap 1 maka dilakukan evaluasi dan dilakukan pengembangan kemasan Tahap 2.

\section{HASIL DAN PEMBAHASAN}

Kegiatan PKM ini diawali dengan mengamati masalah yang terjadi pada UMKM Seafood 21 Pekayon Jaya melalui wawancara dengan pihak mitra dan dapat dilihat dengan lebih jelas pada Gambar 2 yaitu gambar diagram keterkaitan masalah. Setelah itu dilanjutkan dengan melakukan pembuatan kuesioner pendahuluan untuk survey awal. Setelah dilakukan survey pendahuluan kemudian dilanjutkan dengan pembuatan kuesioner conjoin untuk mengetahui atribut yang dianggap penting oleh konsumen.

Berdasarkan kuesioner yang diberikan kepada responden Hasil yang diperoleh berdasarkan survey awal kepelanggan adalah terpilih kombinasi atribut berat isi sebesar 500-600 gram, banyak saus 125-150 gram, varian rasa saus padang, kemasan produk menggunakan zipper, dengan desain luar ditempel sticker menutupi hampir semua bagian, dan desain dalam tidak terpisah. Perancangan produk dibagi menjadi dua dengan melihat atribut berat kepiting sehingga terdapat dua rancangan. Gambar 3 dan Gambar 4 merupakan gambar hasil rancangan berdasarkan hasil kuesioner yaitu dengan menggunakan standing pouch ukuran 16x24 cm yang memudahkan kita membawa produk dikarekan bentuknya yang tidak terlalu besar dan pas ditangan. Pada rancangan diberikan logo merk, beserta instruksi penyajian produk.

Berdasarkan hasil rancangan yang diperoleh dengan menggunakan metode konjoin analisis maka langkah selanjutnya adalah melakukan sosialisasi dan evaluasi terhadap hasil rancangan baru kepada Mitra sebagai upaya untuk meningkatan penjualan dari produk Frozen Seafood UMKM Seafood 21 Pekayon Jaya. Setelah dilakukan sosialisasi perihal hasil rancang ulang kemasan kemudian oleh pihak UMKM Seafood 21 Pekayon Jaya dilakukan implementasi untuk mengetahui seberapa besar peningkatan penjualan yang terjadi dengan adanya perubahan yang dilakukan oleh TIM PKM seperti dapat dilihat pada Tabel 1. Setelah diperoleh hasil penjualan kemudian dilakukan evaluasi hasil oleh tim PKM bersama dengan mitra terkait peningkatan yang diperoleh. Berdasarkan hasil penjualan dari implementasi hasil rancangan yang diperoleh maka jika dilakukan perbandingan diperoleh penjualan produk pada bulan Maret 2021 (setelah implementasi produk baru) lebih baik dibandingkan dengan penjualan produk pada bulan Februari 2021 dapat dilihat terjadi kenaikan penjualan sebesar $22,4 \%$. Saran yang diperoleh untuk pengembangan rancangan tahap 2 adalah dengan menambahkan tabel nutrisi pada label kemasan. PKM ini berlanjut kepada pembuatan rancangan kemasan berdasarkan saran yang ada dan kembali melakukan implementasi. 


\section{Gambar 2}

\section{Diagram Keterkaitan Masalah}

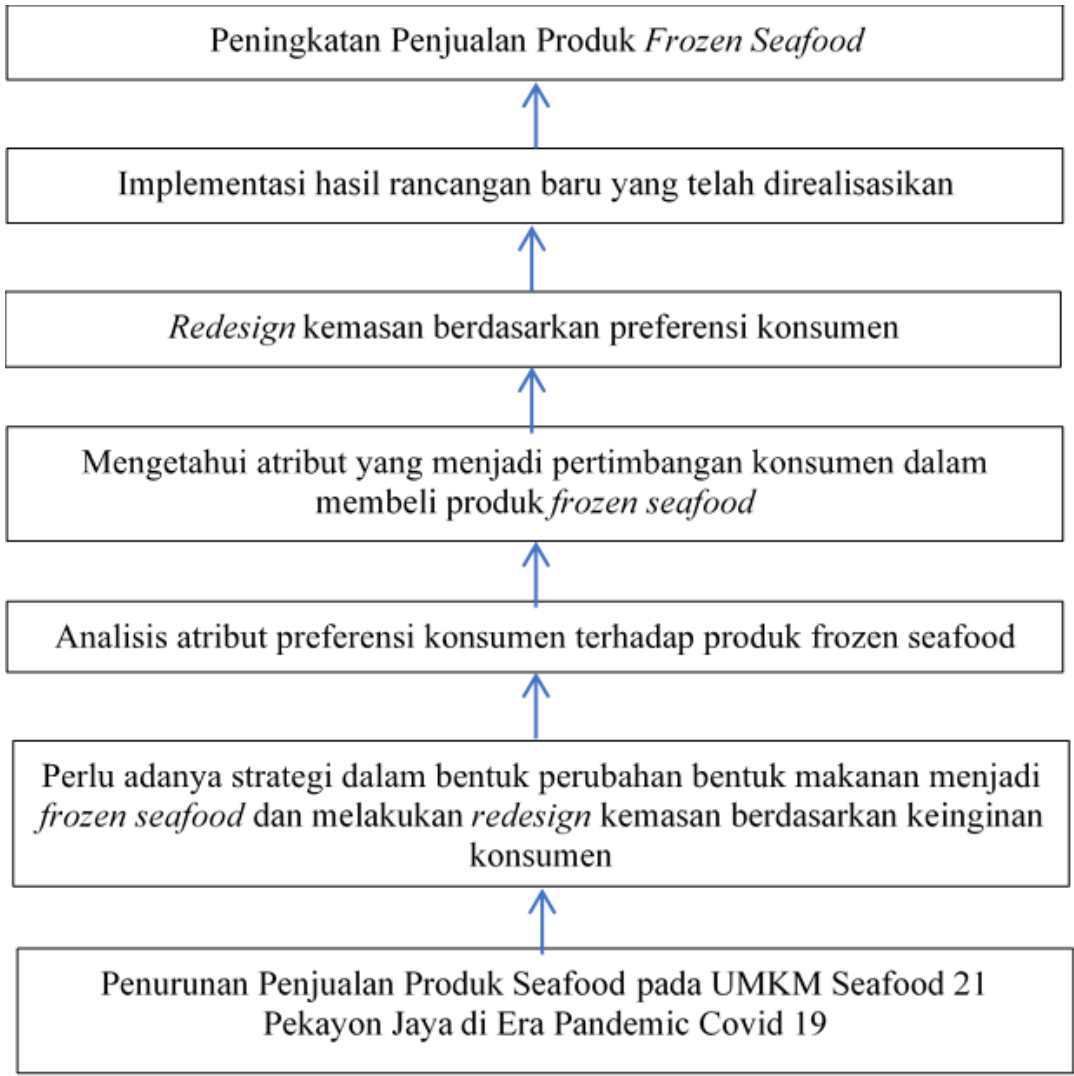

\section{Gambar 3}

\section{Rancangan Kemasan 1}
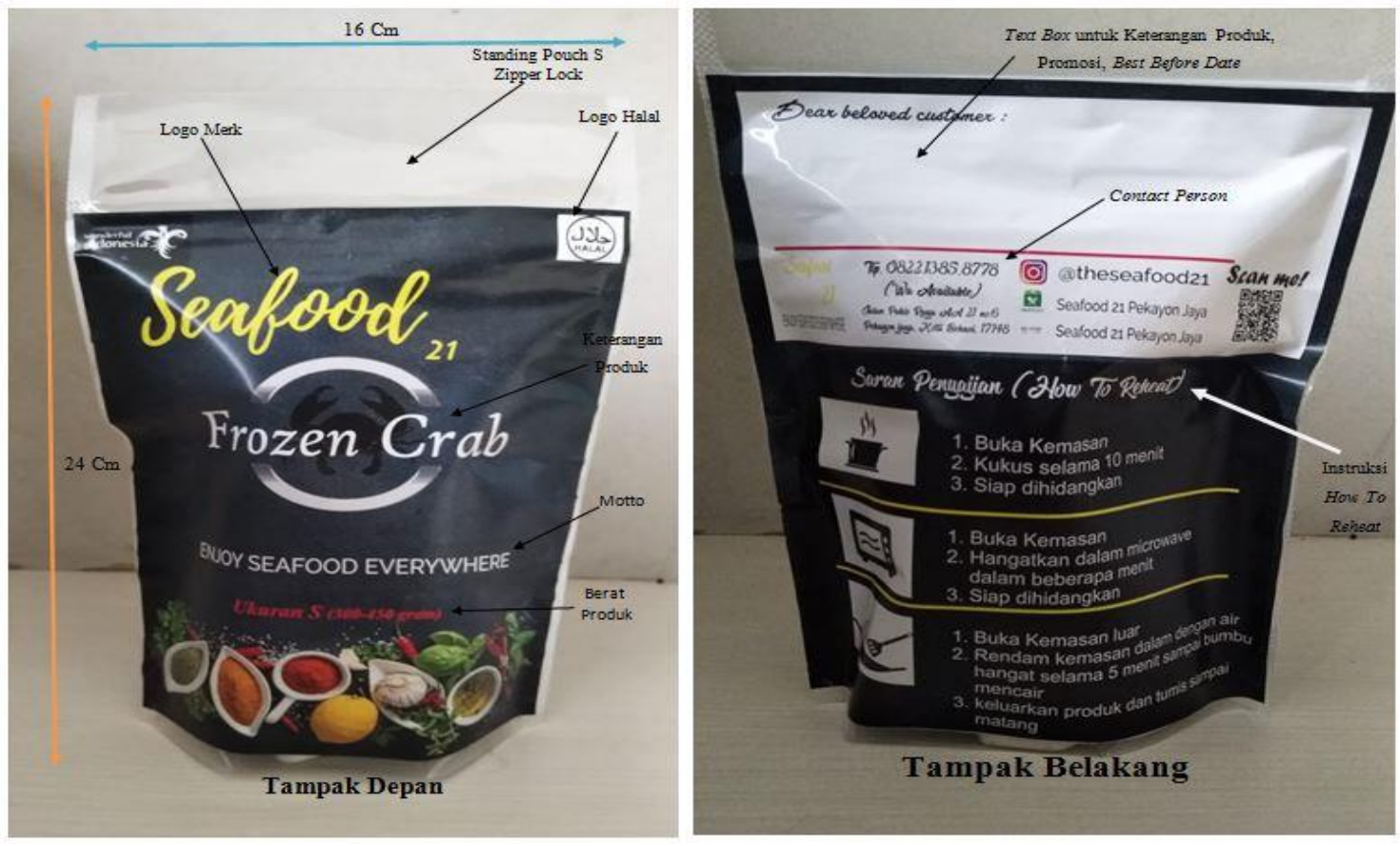


\section{Gambar 4}

\section{Rancangan Kemasan 2}
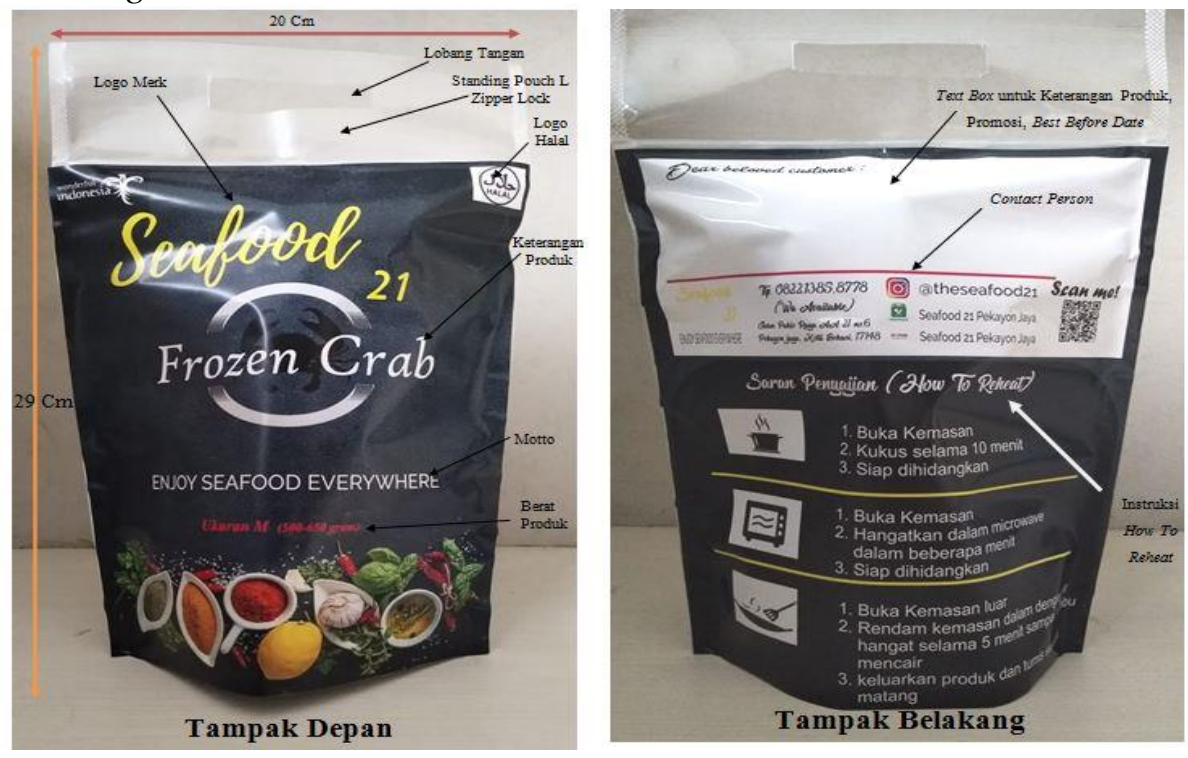

Tabel 1

Perbandingan Penjualan Packing Lama dengan Packing Baru

\begin{tabular}{cc}
\hline Periode & Produk Terjual (Bungkus) \\
\hline Februari 2021 (packing Lama) & 98 \\
Maret 2021 (Packing Baru) & 120 \\
\hline
\end{tabular}

\section{KESIMPULAN DAN SARAN}

Kegiatan PKM ini telah dilaksanakan dengan baik dan masih berlanjut dengan tahap pengembangan. Adapun luaran yang dihasilkan adalah berupa perancangan ulang produk serta realisasi pengembangan dari produk Frozen seafood berbasis conjoint analysis pada UMKM Seafood 21 Pekayon Jaya. Pengembangan dilakukan berdasarkan preferensi konsumen yaitu pada kemasannya. Sosialisasi dari kemasan yang baru telah dilaksanakan dan ditanggapi dengan baik oleh pihak mitra. Selain itu dengan adanya rancang ulang kemasan terbukti dapat meningkatkan penjualan Frozen seafood UMKM Seafood 21 Pekayon Jaya. Pihak mitra mengucapkan terima kasih atas bantuan pendampingan dan sosialisasi tersebut dan menanggapi bahwa keseluruhan pelaksanaan kegiatan telah berjalan sangat baik dan bermanfaat untuk mereka.

\section{REFERENSI}

Surjandari, I. (2010). Conjoint Analysis: Konsep dan Aplikasi. Universitas Trisakti.

Kotler, Phillip \& Armstrong G. (2008). Prinsip-prinsip Pemasaran (Edisi 12 Jilid 1). Erlangga.

Hair, J.F., R. E. Anderson \& R.L. Tatham. (2009). Multivariate with Reading Fourth Edition. Prentice-Hall International.

Hair, J. F. et al. (2014). Multivariate Data Analysis ( $7^{\text {th }}$ ed.). Pearson.

Salomon, L., Kosasih, W. \& Doaly C. O. (2020). Consumer preference analysis of snack using conjoint analysis method (case study: telur gabus). IOP Conference Series: Material Science and Engineering 852(2020)012120, htpps://doi.10.1088/1757-899X/852/1/012120

Salomon, L., Kosasih, W. \& Sukania, I. W. (November 2019). Pendampingan dan pengembangan produk baru pada industri kecil menengah produk makanan ringan guna peningkatan daya saing. Jurnal Bakti Masyarakat Indonesia, 2(2), 131-140. 